\title{
MATERIAL AND TECHNOLOGICAL MODELLING OF CLOSED-DIE FORGING
}

\author{
MATERIALNO-TEHNOLOŠKO MODELIRANJE KOVANJA \\ V ZAPRTEM UTOPU
}

\author{
Ivan Vorel, Štěpán Jeníček, Hana Jirková, Bohuslav Mašek \\ University of West Bohemia, Research Centre of Forming Technology - FORTECH, Univerzitní 22, Plzeň, Czech Republic \\ Stepan.Jenicek@seznam.cz \\ Prejem rokopisa - received: 2014-09-06; sprejem za objavo - accepted for publication: 2015-07-28
}

doi:10.17222/mit.2014.220

\begin{abstract}
In the forging industry, as in other sectors, opportunities are sought for a continuous improvement in the manufacturing productivity. The solution can be found predominantly in optimizing the existing manufacturing processes or developing new ones. However, suspending the production in order to verify optimization proposals often results in substantial financial losses to the company. The present paper describes a design of a comprehensive material/technological model of a production sequence of real-world forging, including the heat treatment in continuous furnaces. A forging used in automotive applications is made of the $\mathrm{C} 45$ steel by closed-die forging. A material/technological model of this forging was developed using data gathered in the real-world forging production and with the aid of a FEM simulation. Good agreement between the specimen processed according to the model and the real-world forging was confirmed with a metallographic observation and tension testing. In both cases, the microstructure consisted of ferrite and pearlite. The ultimate strength of the forging was $676 \mathrm{MPa}$ and its elongation reached $28 \%$. In the material processed according to the model, the ultimate strength was $655 \mathrm{MPa}$ and the elongation level was $32 \%$. The results will be used as the basis for the material/technological modelling in an effort to develop and optimize a controlled cooling sequence to replace the existing heat-treatment process.

Keywords: material/technological model, FEM, simulation, production optimization
\end{abstract}

V kovaški industriji, tako kot v drugih sektorjih, stalno iščejo priložnosti za izboljšave in povečanje produktivnosti proizvodnje. Rešitev je v optimiranju obstoječega procesa ali v razvoju novega. Vendar pa opustitev proizvodnje pri preverjanju predloga optimizacije v podjetju pogosto povzroči občuten izpad prihodka. Članek opisuje celovit materialno-tehnološki model zaporedja proizvodnje realnega kovanja, vključno s toplotno obdelavo v kontinuirnih pečeh. Odkovek, ki se uporablja v avtomobilski industriji, je izdelan iz jekla C45 s kovanjem v zaprtem utopu. Materialno-tehnološki model tega kovanja je bil razvit z uporabo zbranih podatkov v proizvodnji med kovanjem in s pomočjo FEM-simulacije. Dobro ujemanje med vzorci izdelanimi po modelu in realnimi odkovki je bilo potrjeno z metalografijo in z nateznimi preskusi. V obeh primerih sta mikrostrukturo sestavljala ferit in perlit. Natezna trdnost odkovkov je bila $676 \mathrm{MPa}$, raztezek pa $28 \%$. Material, izdelan skladno z modelom, je imel natezno trdnost $655 \mathrm{MPa}$, raztezek pa je bil $32 \%$. Rezultati bodo uporabljeni kot osnova za materialno-tehnološko modeliranje z namenom razvoja in optimizacije faze kontroliranega ohlajanja, ki bi nadomestilo sedanjo toplotno obdelavo.

Ključne besede: materialno-tehnološki model, FEM, simulacija, optimizacija proizvodnje

\section{INTRODUCTION}

In response to current trends in a wide range of sectors of the industry, virtually all companies strive to increase their productivity and cut production costs, while maintaining high quality of products. In the forging industry, the production chain consists predominantly of forming operations, which impart the shape to products, and heat-treatment operations, which impart the desired properties for the intended use of the forgings. Forging and heat treatment of the parts require substantial investments, equipment, labour costs and, in particular, energy costs. In order to manage the costs of these operations, parameters of various treatment processes must be known. A purposeful alteration to the process or a change to a particular parameter can then yield the desired savings. This field has not been fully mapped yet. It is therefore open for material/technological modelling, a tool for obtaining the optimum results.
Material/technological modelling is a technique for studying the processing of materials. It relies on a small amount of material but delivers optimum results, which can be applied to real-world operations. The model uses a small volume of the actual material. The material is processed in a thermomechanical simulator. The simulator applies the desired forming parameters to a specimen and performs heat treatment with very short response times. By this means, a real-world process is simulated. ${ }^{1-3}$ The output is a specimen processed according to the actual processing sequence. The processing parameters can be easily modified and the effect of such changes on the resulting properties can be studied without interfering with the real-world operation.

For the first stage of the investigation, a forging from $42 \mathrm{CrMoS} 4$ steel was selected to find the agreement between the real-world forging and the model constructed from the measured data. ${ }^{4}$ 


\section{EXPERIMENTAL WORK}

The data for the material-technological modelling was gathered in a production where the forgings are processed using conventional forging sequences and where the subsequent heat treatment comprises normalizing or quenching and tempering in continuous heat-treatment lines. With regard to the accuracy of the acquired data, four extensive measurement sessions were undertaken. The purpose was to find the temperature profiles and times for individual operations. The temperatures during forming were measured by means of pyrometers. The times of forming operations were retrieved from the time data $\log$ for the press ram. When the forgings were cooling down on cooling conveyors after the forming, the temperature profiles were measured with pyrometers and monitored with a thermal imaging camera. During the heat treatment, the temperature-profile data were gathered via eight thermocouples. Seven of them were placed on the surface of the forgings in the transport container. One was used to monitor the temperature in the furnace (Figure 1). ${ }^{4}$

To ensure that the data gathered is as accurate as possible and to avoid thermocouples running through the continuous furnaces, a thermally insulated box was developed. Equipped with a data-logging device, the box followed the same route as the transport container with forgings. Deformation and temperature profiles that are virtually impossible to measure were found with the FEM simulations conducted in the DEFORM software. ${ }^{5}$ This simulation also used the input data obtained from an in-situ measurement in the production. With the data obtained in this manner, the material/technological model was constructed.

Referring to the experience gained during the construction of the previous model, an effort was made to use the real-world processing data from the forging line and the heat-treatment line in developing the material/technological model of the forging from the $\mathrm{C} 45$ steel (Table 1). The forging serves as a semi-finished product for a functional part used in the automotive industry (Figure 2).

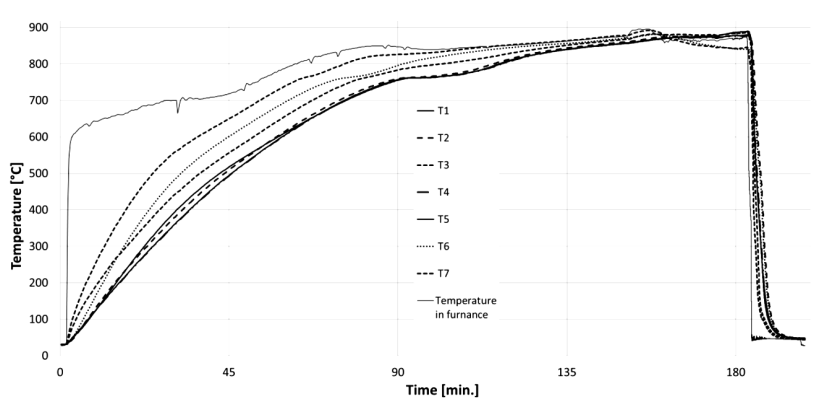

Figure 1: Temperature profile during heat treatment of forgings in a production plant. The curves were measured in various locations of the container (T1-T7).

Slika 1: Temperaturni profil med toplotno obdelavo odkovkov v proizvodnji. Krivulje so bile izmerjene na različnih lokacijah (T1-T7).

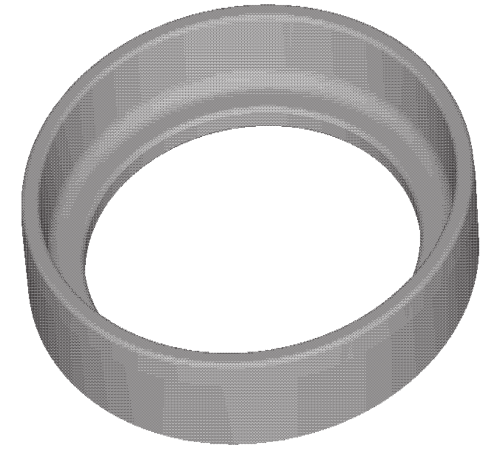

Figure 2: Forged part

Slika 2: Odkovek

Its manufacturing route comprises the forming operations of upsetting, blocking, finish forging and flash trimming. They are followed by normalizing to impart the desired properties. The model was constructed as a tool for further optimization of the forming and heattreating sequences in order to achieve cost savings.

Table1: Chemical composition of C45 steel

Tabela 1: Kemijska sestava jekla C45

\begin{tabular}{|c|c|c|c|c|c|c|}
\hline $\mathrm{C}$ & $\mathrm{Si}$ & $\mathrm{Mn}$ & $\mathrm{Cr}$ & $\mathrm{Ni}$ & $\mathrm{P}$ & $\mathrm{S}$ \\
\hline $0.4-0.5$ & 0.4 & 0.50 .8 & 0.4 & 0.4 & 0.03 & 0.035 \\
\hline
\end{tabular}

The specimens with threaded ends had a diameter of $8 \mathrm{~mm}$. Their gauge length was $16 \mathrm{~mm}$. For the purpose of the material/technological modelling, they were held in the grips of a thermomechanical simulator - Flex Test SE MTS 810 Material Test System (Figure 3). The simulator allows precise control and short response times

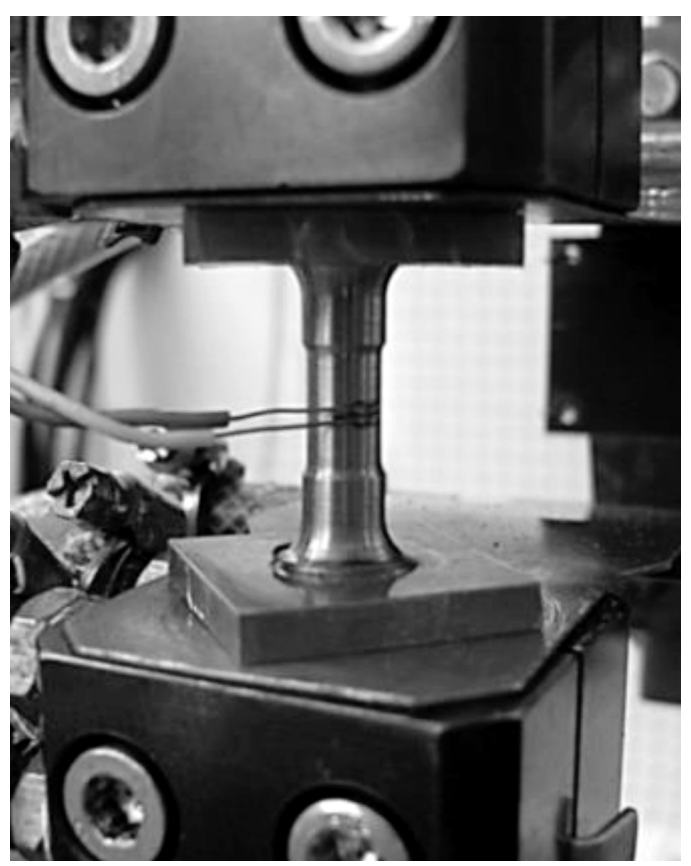

Figure 3: Test specimen in the clamping device of the thermomechanical simulator

Slika 3: Preizkušanec v čeljustih termomehanskega simulatorja 
when performing the thermomechanical treatment, even at high strain rates and in demanding thermal schedules. The specimens were heated with a combination of induction and resistive heating. The strain rate was $0.35 \mathrm{~m} / \mathrm{s}$. The agreement between the model and the real-world forging was evaluated by means of light microscopy, HV hardness test and tension test.

\section{RESULTS AND DISCUSSION}

Using the data measured on the real-world forging, FEM simulations of deformation and temperature profiles at various points of the forging were created. The material/technological model was developed for the point denoted as P10 (Figure 4). This point was chosen because of its importance in terms of the technology of the production.

At this point, the total strain, according to the FEM simulation, was $\varphi=3.6$ (Figure 5a). The largest increase in the strain was found in the first upsetting operation: $67 \%$ of the total strain. In order to impart to the test specimen (when processed according to the material/technological model), the strain corresponding to the upsetting operation, the deformation, must be split into tension/compression modes. Otherwise, the deformation applied to the test specimen could amount to a $90 \%$ reduction in the gauge length. This is not be possible if the requirement for a uniform distribution of the strain is met. Another reason for dividing the total strain, which is normally imparted in a single forming operation, into the tension/compression strokes is the lateral spreading of the test specimen. With the heating method used here and beyond a certain spread of the specimen, the temperature increase due to deformation heating cannot be compensated. If that was to occur, the desired temperature field could not be attained.

The temperature profile at the above-defined point during the cooling after the forming was examined using the FEM simulation. Based on the previous experiments and measurement, the temperature profile during the

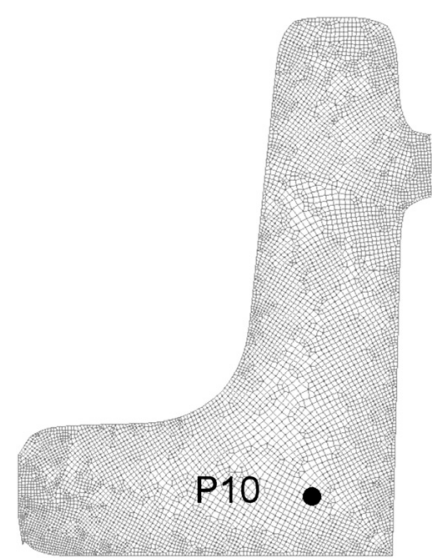

Figure 4: Cross-section of the FEM model of the forging Slika 4: Presek FEM-modela odkovka
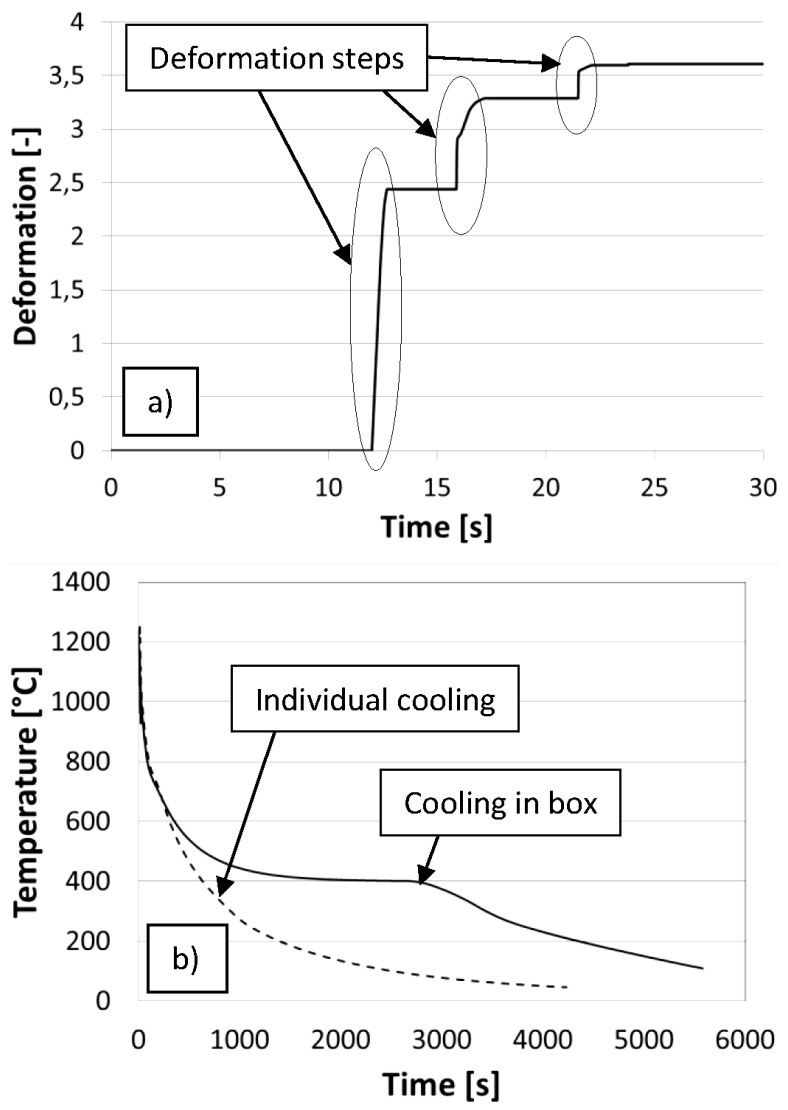

Figure 5: a) Deformation profile during forging of the workpiece, b) temperature profile during cooling after forming

Slika 5: a) Profil deformacije med kovanjem odkovka, b) profil temperature med ohlajanjem po kovanju

cooling was determined for a separately handled forged part and for a forging placed with other forgings into the container (Figure 5b). As the way of the cooling has a significant impact on the properties of the forging, the configuration of the spot where the forging is placed, together with the others, into the container was selected for the next modelling experiments as derived from the previous research.

The plot from the thermomechanical simulator shows that the actual temperature slightly deviates from the prescribed temperature during the simulated upsetting.

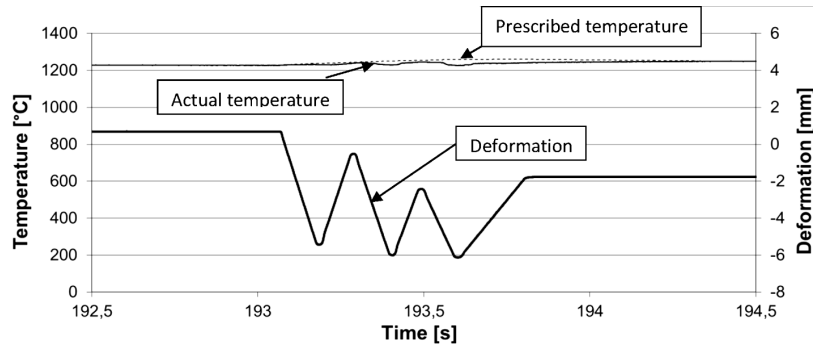

Figure 6: Deformation and temperature profiles during experimental forming of the specimen in the simulator: point P10

Slika 6: Profila deformacije in temperature med eksperimentalnim kovanjem vzorca v simulatorju: točka P10 

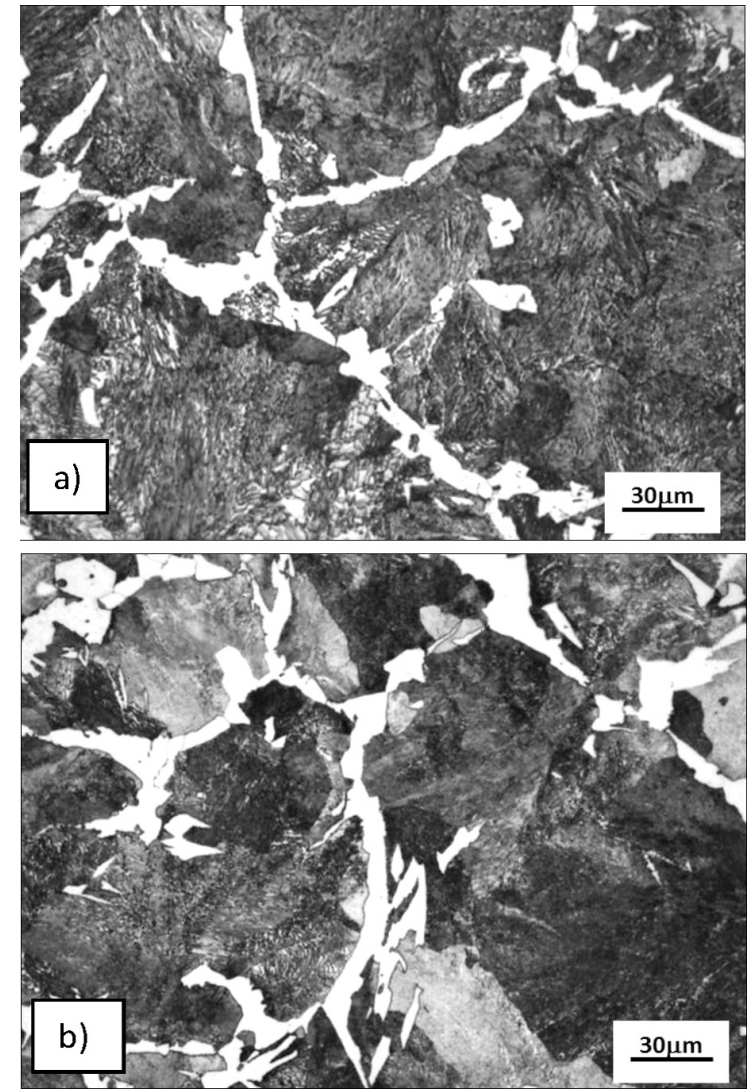

Figure 7: Microstructures of the real-world forging and the specimen after heat treatment - point P10: ferrite-pearlite: a) real-world forging, b) specimen processed according to the material/technological model Slika 7: Mikrostruktura realnega odkovka in vzorca po toplotni obdelavi - točka P10: ferit-perlit : a) realni odkovek, b) vzorec, obdelan skladno z materialno-tehnološkim modelom

This is due to deformation heating. The prescribed and actual deformation plots are in agreement (Figure 6).

The microstructures of the specimen and the realworld forging at the P10 point are in excellent agreement (Figures 7a and 7b). The specimen was processed according to the material/technological model of the conditions at the corresponding point of the forging. The specimen and the real-world forging contained a mixture of ferrite and pearlite. The hardnesses of the specimen

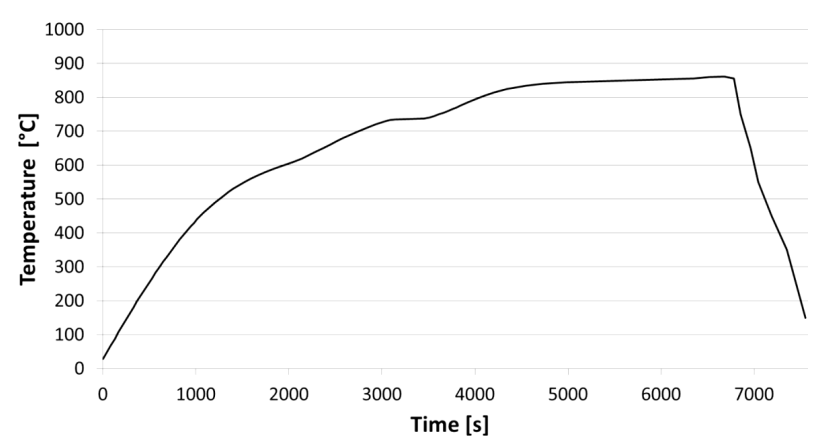

Figure 8: Temperature profile of the real-world forging during normalisation

Slika 8: Profil temperature realnega odkovka med normalizacijo
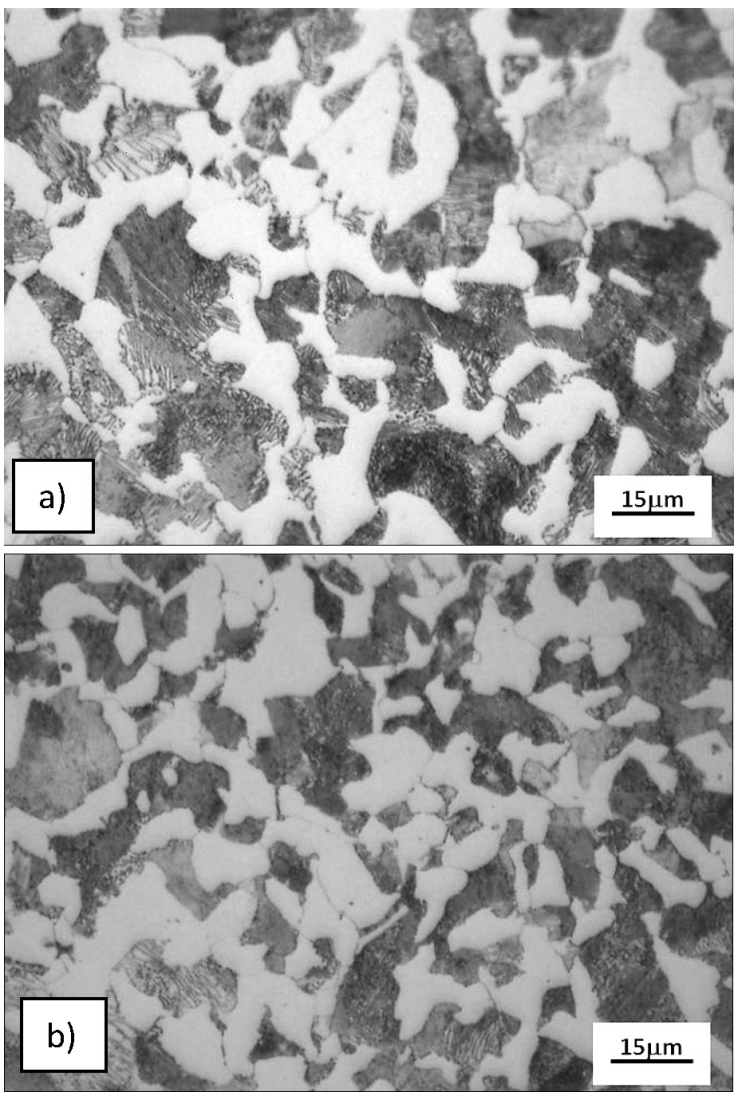

Figure 9: Microstructures of the real-world forging and the specimen after heat treatment - point P10: ferrite-pearlite: a) real-world forging, b) specimen processed according to the material/technological model Slika 9: Mikrostrukturi realnega odkovka in vzorca po toplotni obdelavi- točka P10: ferit-perlit: a) realni odkovek, b) vzorec, obdelan skladno z materialno-tehnološkim modelom

and the forging were $226 \mathrm{HV} 10$ and $221 \mathrm{H} 10$, respectively.

The effect of heat treatment on the final properties of the forging was examined for the purpose of further experiments. The material/technological model was modified using the data from the FEM simulations and the values measured in the real-world heat-treatment process. The forging was normalised at $860{ }^{\circ} \mathrm{C}$ for $120 \mathrm{~min}$ (Figure 8).

The comparison between the microstructures of the real-world forging and the specimen processed according to the model showed that they were in agreement again (Figures 9a and 9b). In both cases, the microstructure consisted of ferrite and pearlite. The hardnesses of the forging and the specimen were $189 \mathrm{HV} 10$ and 192 HV10, respectively.

Table 2: Mechanical properties of the real-world forging and the specimen processed according to the model: point 10

Tabela 2: Mehanske lastnosti realnega odkovka in vzorca izdelanega po modelu: točka 10

\begin{tabular}{|c|c|c|c|}
\hline & HV10 & $R_{\mathrm{m}}(\mathrm{MPa})$ & $A_{5 \mathrm{~mm}}(\%)$ \\
\hline Real-world forging & 189 & 675 & 28 \\
\hline Specimen & 192 & 655 & 32 \\
\hline
\end{tabular}


The table of mechanical properties upon heat treatment (Table 2) shows that the ultimate strength and elongation at the point of interest of the real-world forging were $675 \mathrm{MPa}$ and $28 \%$, respectively. The specimen, processed according to the model describing the same region of the forging, showed the strength and elongation of $655 \mathrm{MPa}$ and $32 \%$, respectively.

\section{CONCLUSION}

Using the data gathered during the production in an actual forging plant and the results of FEM simulations, a material/technological model of a forging was developed. The material/technological model represented the point of the forging, which was very important in terms of the technology of the production. It comprised the forming operations and the subsequent normalising treatment. The validity of the model was examined using specimens of the material. The application of the model of forming led to a significant agreement between the microstructure of the specimen and the corresponding region of the real-world forging. In both cases, a ferritepearlite microstructure was obtained. The hardnesses of the specimen and the forging were $226 \mathrm{HV} 10$ and 221 HV10, respectively. The testing of the model of heat treatment also led to a significant agreement between the microstructure of the specimen and the corresponding region of the real-world forging. In both cases, a ferritepearlite microstructure was obtained. The hardnesses of the specimen and the forging were $192 \mathrm{HV} 10$ and 189 HV10, respectively. By the same token, mechanical properties were found to be in agreement. The strength and elongation of the specimen were $655 \mathrm{MPa}$ and $32 \%$, respectively. In the real-world forging, these were 675 $\mathrm{MPa}$ and $28 \%$, respectively. These results represent a great success in fitting material/technological models to the real-world manufacturing processes. Thanks to the good agreement between the model and the real-world process, opportunities for reducing energy costs and shortening the cycle times can be sought by adjusting the parameters of the model.

\section{Acknowledgement}

This paper includes the results achieved within the project TA02010390 Innovation and Development of New Thermo-Mechanical and Heat Treatment Processes of Die Forgings by the Transfer of Findings Obtained from Material-Technological Modelling. The project belongs to the ALFA Programme and is subsidised from the specific resources of the state budget for research and development through the Technology Agency of the Czech Republic. The paper was also supported from the project SGS-2013-028 Support of Student Research Activities in Materials Engineering Field.

\section{REFERENCES}

${ }^{1}$ B. Mašek, H. Staňková, J. Malina, L. Skálová, L. W. Meyer, Physical modelling of microstructure development during technological processes with intensive incremental deformation, Key Engineering Materials, 345-346 (2007), 943-946, doi:10.4028/ www.scientific.net/KEM.345-346.943

${ }^{2}$ B. Mašek, H. Jirková, L. Kučerová, A. Ronešová, J. Malina, Material-Technological Modelling of Real Thin Sheet Rolling Process, METAL 2011, Ostrava 2011, 216-220

${ }^{3}$ B. Mašek, H. Staňková, A. Ronešová, D. Klauberova, Modelling Structure Development with High Gradient of the Changes in Physical Parameters, Conference on Advances in Heterogeneous Material Mechanics ICHMM-2008, Huangshan, China 2008, 390-393

${ }^{4}$ V. Pileček, F. Vančura, H. Jirková, B. Mašek, Material-Technological Modelling of Die Forging of $42 \mathrm{CrMoS} 4$ Steel, Mater. Tehnol., 48 (2014) 6, 869-873

${ }^{5}$ M. Fedorko, L. Maleček, Construction of Numerical Model of Forging Process of Four-Pole Rotor Shaft, Hutnické listy, LXV (2012) 4 